Khazanah: Jurnal Studi Islam dan Humaniora

ISSN: 0215-837X (p); 2460-7606 (e), Vol. 17 (2), 2019, pp. 191-208

DOI: 10.18592/khazanah.v17i2.3211

Submit : 14/08/2019 Review : 24/09/2019 Publish : 31/12/2019

\title{
FROM PRINT TO SCREEN: METHODOLOGY, MEDIA, AND TRANSITION OF QUR'ANIC LEARNING IN INDONESIA
}

\author{
Muhammad Zulfar Rohman \\ Universitas Islam Negeri Sunan Kalijaga Yogyakarta \\ zulfarr@gmail.com
}

\begin{abstract}
This article aims to discuss the shift in the methodology of Qur'anic learning in Indonesia that is influenced by media. There are four cases used to map the contestations in the traditional era: Baghdadi, Qiroati, Iqro', and Yanbu'a. Those have the same characteristic, namely face-to-face learning which is then challenged by the new media that infiltrate the Islamic world. One of the new media described in this paper is the Qur'anCall that is initiated by the PPPA Daarul Qur'an led by the famous preacher Yusuf Mansur. This is a learning and teaching platform for the Qur'an based on a video call. The character possessed by the Qur'anCall is very different from the traditional methodology. Based on this issue, the author examines the changes in Qur'anic learning in the traditional and modern eras then elaborates on the effects that have caused. The finding shows that there are degradations from various performative aspects that are inherent in the traditional methods of Qur'anic learning. Furthermore, the authority of the Qur'anic teacher who was once held by the Qur'anic experts can be in the hands of people with low qualifications.
\end{abstract}

Keywords: Method of Qur'anic Learning; Media; the Qur'anCall

\section{Introduction}

The role of new media in the present has penetrated various aspects of human life, including religion. The relationship of religious people with each other and with their religious texts is getting closer and not insulated. Every person with any background gets the same opportunity and convenience in accessing the scriptures. Various religious followers are increasingly free to share their religious understanding while the shift of religious authority becomes inevitable. As a result, new authorities emerge and change the existing "religious experts" standard. Besides, the media also exposes a new background in the understanding and practice of the scriptures, ${ }^{1}$ including in the process of learning the Qur'an in Indonesia.

The authority of Qur'anic teaching is an interesting issue to be discussed. Before everything is digitalized as today, people who want to learn the Qur'an will come directly to a trusted teacher, Ustaz, or Kyai. The motive for those who come to the teacher is usually not only to learn the Qur'an but also to ask for the blessing. There are two kinds of traditional learning centres that are established institutions like Islamic boarding schools, and informal ones such as mosques, prayer rooms, or

${ }^{1}$ Leah Kinberg, "Contemporary Ethical Issues," in The Blackwell Companion to the Qur'an (Victoria: Blackwell Publishing, 2006), 465. 
surau. The learning processes use the methodology of reciting the Qur'an such as Bagbdadi, Iqro, Qiro'ati, and Yanbu'a. The estimated time of learning usually takes a long time until a student will receive a diploma. This is the process of transmitting authority.

The configuration of traditional Qur'anic learning as above has slowly but surely shifted since new media emerged. Through the Internet, Islamic knowledge has not only spread through print media but also screen. As a result, Muslims mostly study religious knowledge on the Internet, including learning to recite the Qur'an which automatically requires no interaction at all. In Rudolph language: embodied transmission of Islamic knowledge is being eclipsed by disembodied consumption. ${ }^{2}$ Someone can learn without meeting directly with the teacher then sanad connectivity is considered insignificant. Other motives such as asking barakah (blessing) will fade. Some textual guidance of the particular recitation began to be abandoned because they were replaced by the new media such as audio, audio-visual, or even a video call.

More specifically, the author would like to reflect on this shift and examine the extent of the impact. The window that the author uses to enter this discourse is an online Qur'anic learning platform, Qur'anCall. This platform is created by Program Pembibitan Penghafal Qur'an (PPPA) Daarul Qur'an which promotes an Online Program of Qur'anic Learning.

\section{Method}

This article is a research result which describes the development of qur'anic learning in Indonesia, especially in methodology, media, and transition aspect. There are four types used to map the contestations in the traditional era: Baghdadi, Qiroati, Iqro', and Yanbu'a. Those have the same characteristic, namely face-to-face learning. In recent years, those methods are challenged by the new media that infiltrate the Islamic world. One of the new media described in this article is the Qur'anCall initiated by the PPPA Daarul Qur'an.

\section{Contestation of Methodology: Traditional Era}

Dialectics between Indonesian people and the Qur'an is always lively with a variety of rituals. Starting from the most basic activities such as learning to recite the Qur'an, memorizing the Qur'an to the dynamics of interpretation, those are always rich in thought. In learning to recite the Qur'an itself, it has never been stagnant with one methodology only since Islam first came to Indonesia until now. There are various methodology such as Baghdadi, Iqro', Qiro'ati, Yanbu'a, etc. In this shift of methodology, there was a contestation to prove the effectiveness of each method in producing reliable Qur'an readers. The author aims to reflect on some methodologies that can be referred to in the traditional category. The traditional that is mentioned here should not be based on a periodization but rather a marker when the methodologies are highly dependent on printed media in the learning process.

${ }^{2}$ Rudolf T. Ware III, The Walking Qur'an: Islamic Education, Embodied Knowlwdge, and History in West Africa (Chapel Hill: The University of North Carolina Press, 2014), 71. 


\section{Baghdadi}

This method, which is also known as the "spell" method, has long dominated the learning of the Qur'an in Indonesia. While it originated from Baghdad during the reign of the Abbasid caliph, the founder of this method is still unknown. In Indonesia, it has taken more than a century for its massive development. The learning materials are arranged from concrete to abstract ones, from easy to difficult ones, and from general to detailed or specific materials. In general, Baghdadiyah requires seventeen steps. Thirty letters of the Hijaiyyah are always fully displayed at every step, as the number is a central theme with a variety of variations.

Variation of each step gives a sense of aesthetics for students in the term of easy listening because it has certain rhymes. This method is taught both classically and privately. Some of the advantages of the Baghdadi method are: ${ }^{3}$ (1) Learning materials are arranged comprehensively; (2) 30 letters of the Hijaiyyah are almost always displayed at every step in the entirety as a central theme; (3) Patterns of sound and arrangement of letters (wazan) neatly organized; (4) The developed skills of spelling become the main attraction; (5) Tajweed material is fundamentally integrated into every step. Some disadvantages are: ${ }^{4}(1)$ The original Baghdadiyah method is difficult to be traced because it has undergone several modifications; (2) The material presented seems tedious; (3) The appearance of several similar letters can complicate student's experience; (4) It takes a long time to be able to recite the Qur'an.

\section{Qiroati}

Baghdadi, which had previously spread widely in Indonesian community, then had been slowly forgotten because the method is considered less practical and efficient, especially for people who want to recite the Qur'an faster. This is as experienced by Ustaz H. Dahlan Salim Zarkasy in teaching children to recite the Qur'an in 1963 in Semarang. Besides being a teacher, he was also a trader. When he visited various cities, he found the same problem, the decrease of the effectiveness in using Baghdadi method. Responding to the issue, Ustaz Dahlan tried to create a new method called Qiroati.

Seeing the effectiveness of this method, in 1966, H. Ja'far, a Kyai from Semarang, invited Ustaz Dahlan to ask for the blessing of K.H. Arwani Amin Kudus so that this method can be spread more widely. After it is corrected and revised by him, the book of Qiroati method began to be introduced to the public. What also needs to be noted from the history of this method is when Ustaz Dahlan opened the Raudhatul Mujawnidin Kanak-Kanak al-Quran (TKQ). Because the success of this institution produced children who were proficient in reciting the Qur'an, the Qiroati method eventually spread throughout Indonesia. ${ }^{5}$

\footnotetext{
${ }^{3}$ Saiful Mujab and Ida Vera Sophya, "Metode Baca Al-Qur'an,” Elementary 2, no. 2 (2014): 338.

${ }^{4}$ Mujab and Sophya, 338.

${ }^{5}$ Siti Farida Hanum, Efektivitas Penerapan Metode Qiraati Terbadap Keterampilan Membaca Huruf Al-Qur'an Di Play Group Plus Al-Afkar W aru Sidoarjo (Surabaya: UIN Sunan Ampel, 2019), 16.

Khazanah, Vol. 17 (2), 2019 
In my opinion, in contrast to the Baghdadi method which is more like spelling, Qiroati teaches directly the sound of each letter with a barakat. The structure is also different because the Baghdadi method consists of one volume only while Qiroati consists of several volumes with a systematic and organized arrangement of difficulties. Besides, the Qiroati method has also been introduced to tajwid science. The instructor of this method must also have the Qiroati shahadah (certificate) so that not everyone has the authority to teach like the previous method. Based on these four particular factors, slowly but surely, the Qiroati overthrows the dominance of the Baghdadi method in Indonesia.

\section{Iqro'}

This method, which is famous in urban communities is compiled by As'ad Humam, a trader in Beringharjo Market, Yogyakarta City. As a trader, he met and became acquainted with various colleagues from various cities. Among these are K.H. Dachlan Salim Zarkasyi, the founder of the Qiroati method. Because of his interest in the Qiroati method, As'ad Humam has been using this method for teaching since 1975. However, then, Kyai As'ad found some difficulties because the Qiroati method according to him was not tartil and there was no tajwid. Responding to this, Kyai As'ad tried to improve it so it can be more easily understood by students.

Between the two previous methods, iqro' is more detailed in describing the practical details of its use. In the iqro' method, the instructions for use are explained as follows:

a. System

1) Cara Belajar Siswa Aktif (CBSA) is a learning technique of active student where the teacher explains the subject, then, the students recite repeatedly by themselves, while the teacher only listens, no guiding but only giving examples of subjects.

2) Private. Check one by one in turn.

In a classical way, students are grouped based on their abilities. Next, the teacher explains the lesson points classically using visual aids, and students are randomly asked to read the material.

3) Assistance. Students in advance can help teaching others.

b. Regarding the titles, the teacher immediately gives examples of recitation, so it does not need much explanation. Students are not introduced to the terms fathah, tanwin, sukun, etc because the important thing is that the students recite correctly.

c. Once the letters are recited correctly, they should not be repeated.

d. If students are wrong in reciting letters, the teacher must sternly warn and reciting it to be disconnected, if necessary suppressed.

e. If students recite the wrong letters, the teacher only correct the wrong ones, by warning, for example with the words "eeee ... watch out ... stop..etc. If the students still make an error after being warned, the teacher gives the memory bridge. For example, students forget to recite the letter (\lrcorner$)$ and Ustaz just remind it by pointing out "if there is no dot, please read $\operatorname{Ra}^{\prime}(\jmath)$ and so on. If you still forget, then the actual recitation is shown. 
f. Lesson one contains the introduction of satanic letters, so before mastering correctly, students cannot move on to the next volume. Meanwhile, if the students are not still fluent after doing their best, so the teacher lets them be.

g. For students who truly master the lesson and desire in completing their learning as soon as possible, they can recite it by skipping some parts.

h. For the final assessment (Evaluasi Belajar Tahap Akbir/EBTA), the examiner will be determined. ${ }^{6}$

The practical instructions above are always included in the 6 volumes of the book Iqro'. Besides, it is also explained that this method has several characteristics or characteristics: (1) Direct Recitation; (2) CBSA (Learning Technique of Active Student); (3) Private / Classical; (4) Modules; (5) Assistance; (6) Practical; (7) Systematic; (8) Varies; (9) Communicative; and (10) Flexible. ${ }^{7}$

Compared to the previous two methods, the Iqro' method is more systematic. It appears based on the technical description above. Then, because this method is a synthesis of the Qiroati method, it is easy to find the fact that the influence of the Qiroati is still very obvious.

\section{Yanbu'a}

Yanbu'a is a method of learning to recite, write and memorize the Qur'an which is compiled according to the rules of Rasm Utsmany. This method was introduced by Pondok Tahfiz Yanbu'ul Qur'an. There are at least three reasons for the birth of this method: first, it is an effort to maintain good relations between alumni of the Pondok and Kyai; second, proposals from the Ma'arif Education Institute and Muslimat, especially the branches of Kudus and Jepara; and the last, to maintain uniformity of reciting the Qur'an. ${ }^{8}$

The Yanbu'a method began to be written on November 22, 2002, which coincided with the 17th of Ramadan $1423 \mathrm{H}$, and took two years to complete. The publication was done in some stages. There are some steps to teach the Yanbu'a method as follows:

a. The teacher gives greetings before kalam and does not greet before students come.

b. The teacher recites the Khadlroh (p. 46 vol.1) then the students recite al-Fatihah and the opening prayer

c. The teacher tries to make the child active and independent

d. The teacher does not lead the student's reciting but guides it by: (1)Explaining the subject (underlined); (2) Giving the right example; (3) Listening to the students' reciting patiently, thoroughly and decisively; (4) Reminding the wrong reciting with clues, beats, etc; (5) When the students recite correctly, the teacher carries forward from one page to several pages, according to students' abilities; and (6) If

${ }^{6}$ As'ad Humam, Cara Cepat Membaca Al-Qur'an (Yogyakarta: Team Tadarus AMM, 2000), 3.

${ }^{7}$ Humam, 3. 2004), 1.

${ }^{8}$ Ulil Albab, Bimbingan Cara Mengajar Yanbu'a (Kudus: Pondok Tahfidz Yanbu’ul Qur'an,

Khazanah, Vol. 17 (2), 2019 
the students cannot keep up and do many mistakes, they cannot continue and must repeat.

e. Study time is about 60-75 minutes and divided into three parts:

1) 15-20 minutes for prayer, attendance, explaining the subject or reciting classically.

2) 30-40 minutes to teach individually/ listen to the students one by one, while those who have not advanced yet, they have to write.

3) 10-15 minutes giving additional lessons such as Fashalatan, prayers, etc. Then the teacher gives some advises and leads the closing prayer. ${ }^{\text {p }}$

The Yanbu'a method consists of 7 volumes. Similar to the Iqro method, in my opinion, the Yanbu'a also cannot be separated from the influence of the Qiroati method. This is evident from the format of the content which consists of the core material titles, then underneath are the sentence fragments from the Qur'an that correspond to the material. What is special about this method is that students are taught to write a pegon script. Besides, at the beginning of each volume, the technical instructions are written for teaching, which indeed each volume is different. At the end of several volumes, it attached badlroh. This is not surprising considering that the Yanbu'a method was born from a boarding school which has Nabdlatul Ulamaoriented.

\section{Characteristics of Traditional Qur'anic Recitation Method}

In the traditional method of learning the Qur'an, a student is required to meet (talaqqi) directly to the teacher. Even the prospective students will usually come with their families. The tradition that is often referred to by the term Sowan is like a contract that the student is handed by parents to be educated and then the teacher accepts it. The learning process is usually done in places of worship such as mosques and prayer rooms, or educational institutions such as TPQ or Islamic Boarding Schools.

What is interesting about the characteristics of the traditional methodology of the Qur'an reciting is the strict specification for a teacher. This indicator is less visible when the Baghdadi method still dominates, but it become obvious when the Qiroati and Yanbu'a methods are introduced. Both of these methodologies have special learning programs that must be followed by prospective teachers. In this program, prospective teachers are required to study again starting from the most basic volumes, even though they are already fluent in reciting the Qur'an or even memorizing the Qur'an (bafiv). This is to ensure that their recitations are under the standards set by the methodology. This kind of standardization often results in a phenomenon where someone who already has a teaching certificate of one method, will be claimed as faulty or even useless according to other methods. However, on the other hand, the strictness on the specifications of these teachers can close the gap of the emergence of impromptu teachers who are less competent.

\footnotetext{
${ }^{9}$ Albab, 5.
} 
Traditional methods of learning the Qur'an require a relatively long time. Usually, the earliest material that must be mastered by students is reciting Surah alFatihah. In my opinion, this is closely related to the doctrine that al-Fatihah is a compulsory recitation in prayer so that traditional Qur'anic learning feels the need to correct students' recitation of al-Fatihah. In some pesantren, some require reciting tabiyat if students have mastered the recitation of al-Fatihah for the same reason. The process of teaching al-Fatihah itself takes weeks or even months. This is what makes students stop and choose a faster method. Some criticize this kind of method to fall into israf (excessive recitation of the Qur'an). Such criticism is disputed with the argument that in the learning process, it is necessary to read as perfectly as possible, correctly in tajwid and makbraj, so that the recitations can be attached in the oral of a student. It aims to be applied correctly in his tajwid and makhraj even he reads another surah quickly.

Furthermore, in the traditional method, there are several motives apart from just learning the Qur'an. For instance, the students actually expect blessings from the teacher. This motif was born from the feeling that the Qur'an is a perfect guidance. From here, Muslims are motivated to learn to read, memorize, and understand the meaning of the Qur'an. Based on this feeling, various practices were born, ${ }^{10}$ including asking for a blessing from the teacher of the Qur'an so that a student can gain knowledge and success when he has graduated.

\section{Qur'anCall: Technology Shifts Methodology}

The spread of a religion cannot be separated from the influence of the media that facilitates it. In its development, Islam is also affected by the new media. There are at least three periods of Islam meets the media. First, in the middle of the eighth century when Muslims came to know paper. This paper eventually became an influential media in spreading Islam, because Islamic knowledge was written through it. Secondly, when Islam began to recognize printing. The influence of writing can be further optimized because, with the presence of printing, the process of copying and printing became easier. It took a short time with unlimited quantities. Third, digitalization in the modern era. In this era, Islamic guidance including the Qur'an began to circulate in the form of commodities, both in the form of audio, software, and applications in the computers and other gadgets. ${ }^{11}$ Here I examine one important shift in the development of learning to recite the Qur'an in the modern era in Indonesia with the presence of Qur'anCall. This is a platform that brings Islamic teachers or the Qur'an teachers with students to study the Qur'an online via a video call, with a curriculum designed by the PPPA Daarul Qur'an. However, I need to outline some important things behind this platform before.

${ }^{10}$ Anna M. Gade, Perfection Makes Practice: Learning, Emotion, and The Recited Qur'an in Indonesia (USA: University of Hawai'i Press, 2004), 168.

${ }^{11}$ Tati Rahmayani, "Pergeseran Otoritas Agama Dalam Pembelajaran Al-Qur'an," Maghza 2, no. 2 (2018): 192.

Khazanah, Vol. 17 (2), 2019 


\section{Yusuf Mansur: Dai cum Motivator}

"Kalau pengen apa-apa, sedekab". Certainly, most people will associate the phrase with Ustaz Yusuf Mansur. Indeed, the Betawi-born Ustaz was very popular with his alms movement. ${ }^{12} \mathrm{He}$ is a preacher, writer, and entrepreneur who has appeared in various printed-books, online programs, television shows, etc. He was born in Jakarta, on December 19, 1976 and once studied at the Syari'ah Department of IAIN Syarif Hidayatullah, although he did not graduate. Together with two colleagues, he founded the Sekolah Tinggi Ilmu Komputer Cipta Karya Informatika.

The bitter experience is the best lesson. It was the same with the journey of Ustadz Yusuf Mansur, who had tried to be involved in the informatics business but instead made him in debt and even caused him to go into detention for two months. The same thing was repeated in 1998. Getting out of prison is a turning point in his life. He restarted the business from scratch by selling ice at the Kali Deres terminal. Then his business gradually grows and develops.

His small success then led him to become acquainted with a policeman who brought him to a non-governmental organization (Lembaga Swadaya Masyarakat/ LSM). During his active time at the NGO, he wrote the book "Wisata Hati, Mencari Tuhan yang Hilang". In that book, his experiences in prison inspired him to invite people doing charity. The book sold well in the market and he was eventually invited to various places to give lectures. His simple language with parables close to daily life made him liked. Furthermore, Yusuf Mansur is also noted as a motivator at Daarut Tauhid led by Aa Gym. ${ }^{13}$ His experiences with Aa Gym inspired YM to establish the PPPA Daarul Qur'an Foundation which was more focused on the education of the Qur'an.

\section{The PPPA Daarul Qur'an Foundation: Diaspora of Tahfiz School}

March 29, 2007 is an important history in which Yusuf Mansur differentiated his preaching movement by publicly launching Program Pembibitan Penghafal al-Qur'an (PPPA) Daarul Qur'an. ${ }^{14}$ In fact, this program began in 2003 when Yusuf Mansur led several santri in the Bulak Santri Musholla. From the start, the institute concentrated on efforts to manage alms to be implemented in the program of tahfiz Qur'an. Here I classified PPPA Daarul Qur'an's moves in four major programs: ${ }^{15}$ (1) Education and da'wah: Pesantren Tahfizh Daarul Qur'an, Tahfizh House, Simpatik Guru, BTQ for Leader, Takhasus Scholarship, Qur'anCall, and Mobile Qur'an; (2) Social Humanity: Humanitarian Services, Ambulance Services, SIGAB, and Overseas Programs; (3) Community Development: Kampung Qur'an and DAQU Preneur; (4) Social Business: Klinik DAQU Sehat and DAQU Agrotechno.

\footnotetext{
${ }^{12}$ Mansur Hidayat, "Sedekah Online Yusuf Mansur: Otoritas Dan Bahasa Agama Di Media Sosial," Fikrah 6, no. 1 (2018): 19.

${ }^{13}$ M. Maskhuri, Sedekah Dan Gerakan Dakwah Islam: Studi Pemikiran Yusuf Mansur (Semarang: IAIN Walisongo, 2011), 65.

${ }^{14}$ Yayasan Daarul Qur'an Nusantara, Profil Lembaga PPPA Daarul Qur'an (Tangerang: Daarul Qur'an, tt), 5.

${ }^{15}$ Nusantara, 12. 
In the historical context of the relationship between Indonesian people and the Qur'an, tahfiz Qur'an has been developing for a long time. If it is traced, the tradition of memorizing the Qur'an has possibly existed since the scholars of Indonesia studied and memorized the Qur'an in Hijaz in the 18th century. Upon returning to the archipelago, then they opened the Qur'anic studies until many people memorized the Qur'an. Some argue that this tradition has existed since the Walisongo or the 15th century. Regardless of the emergence, this tradition was born from the oldest religious education institution in Indonesia, which is known as pondok pesantren. ${ }^{16}$ In pesantren programs, tahfir is usually managed in traditional ways. This aspect becomes the major focus of the PPPA Daarul Qur'an to enter the market of Qur'anic learning in Indonesia. It offers a tahfiz program that is managed in a modern and integrated way with the alms program both offline and online. Even on April 5, 2017, it is recorded that the PPPA successfully collected funds of $671,352,623,502$ rupiahs with a total of 68,519 donors. ${ }^{17}$

Moreover, this program is carried by Yusuf Mansur, who is one of the most popular preachers today. Besides, he was asked to open the Tahfiz Pesantren or Tahfiz House in collaborating with some entrepreneurs as the funders. Inevitably, in less than ten years, Pesantren Tahfiz by Yusuf Mansur spread rapidly in various cities. With this success, the PPPA continues to develop various programs that are packaged in a modern way. Among them is an online program of Qur'anic learning called Qur'anCall.

\section{Qur'anCall: Initiation or Appropriation?}

Education, as one dimension of human life in the modern era, cannot be separated from the influence of the Internet. It is proven by the use of the Internet as a learning medium, known as online learning. In general, online learning is:

The uses of the Internet to access learning materials, to interact with the content, instructors, and other learners; and to obtain support during the learning process, to acquire knowledge, to construct personal meaning, and to grow from the learning experience. ${ }^{18}$

Wherever and whenever is the convenience offered by online learning. This phenomenon also permeates religious learning, including learning to recite the Qur'an online managed by Qur'anCall.

Qur'anCall is a platform that brings teachers and students together to learn the Qur'an online. Qur'anCall aims to build a community of the Qur'an learners and teachers, as well as to shape a Muslim who likes to recite the Qur'an with the correct makbraj and tajwid as his habit. Qur'anCall brings together anyone who wants to learn the Qur'an with the best Qur'an teachers in Indonesia. ${ }^{19}$

\footnotetext{
${ }^{16}$ Ahmad Atabik, “The Living Qur'an: Potret Budaya Tahfiz Al-Qur'an Di Nusantara," Jurnal Penelitian 8, no. 1 (2014): 168.

${ }^{17}$ Hidayat, "Sedekah Online Yusuf Mansur: Otoritas Dan Bahasa Agama Di Media Sosial," 7.

${ }^{18}$ Mohamed Ally, "Foundation of Educational Theory for Online Learning," in The Theory and Practice of Online Learning (Edmonton: AU Press, 2008), 17.

${ }^{19} \mathrm{https:} / /$ qurancall.id/, accessed May 31, 2019.

Khazanah, Vol. 17 (2), 2019 
This program can be accessed at https://qurancall.id/. The design is very user-friendly because students or teachers can access it only with a laptop or PC that has a camera and internet. In my opinion, this program seems to be a metamorphosis of the previous Qur'anCall program that was launched by the PPPA. However, in the previous program, learning activities could only be done by voice (via telephone). The Qur'anCall referred to this study is web-based learning via video call.

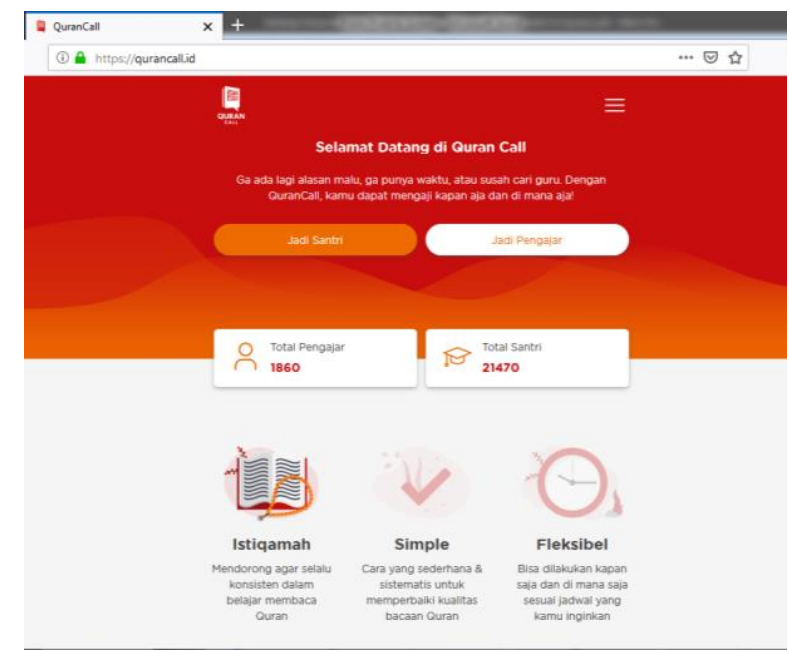

Figure 1. Qur'anCall Homepage

The homepage convincingly shows the motto of the Qur'anCall: "Reasons for embarrassment, lack of time, or difficulty finding a teacher are no longer valid. With Qur'anCall, you can recite the Qur'an anytime and anywhere". ${ }^{20}$ This motto aims to remove the various deficiencies of traditional learning methods in reciting the Qur'an as discussed earlier. First, embarrassment. Sometimes it prevents someone, mostly elder people to learn the Qur'an especially in a traditional way that requires face-to-face meetings. Second, activity. It is also an obstacle which makes people unwilling to learn the Qur'an, especially for those who have high mobility. Third, difficulty to find a teacher. Because of many traditional methods in learning the Qur'an, sometimes they make people confused to find a teacher. With the presence of the Qur'anCall, the three obstacles above are successfully resolved.

If it is observed, the actual concept of learning that is offered by Qur'anCall is already common. Even if it is considered in detail, in my opinion, this platform is very similar to Qutor. Qutor is also an online platform of Qur'anic learning, but it has many more programs and consists of online Qur'an instructors who spread across various countries such as the UK, USA, Egypt, Saudi Arabia, Australia, Canada, Germany, Ukraine, Turkey and Malaysia. ${ }^{21}$ The number of students registered at Qutor was 14,543 with 449 tutors and 70,758 session classes completed. The similarity

${ }^{20}$ https:/ / qurancall.id/, accessed May 31, 2019

${ }^{21}$ bttps://qutor.com/, accessed June 27, 2019 
is also very apparent where both the Qur'anCall or Qutor display several similar things: the number of students or teachers, the three conveniences offered from learning the Qur'an online, testimonials from students who have learned from each platform, free trial for new students, and the absence of strict standards for registering as a teacher on the main website.

From the above analysis, it is very clear that the Qur'anCall is an Indonesian version of Qutor. However, for more discussion, I examine this platform by reviewing two perspectives, namely the perspective of students and the perspective of the teacher, as will be explained below.

\section{Santri: Learning Material, Methodology, and Commodification}

Based on data displayed on the Qur'anCall homepage, the total number of students applied in this program is 21,500 in July $2019 .{ }^{22}$ As a relatively new program, the Qur'anCall is considered successful. As a public school, a student have to register and complete his data information as follows:
a. Must input a full name
b. Must input an active e-mail to activate the account which will provide a reminder of learning schedule, and be active in Qur'anCall.id.
c. Must input an active telephone number so the Qur'anCall.id can contact any time if needed.

d. Choose the appropriate sex based on the Identification Card (KTP)

If the registration is successful, the student must log in with the username and password that is already owned. After logging in, students will be presented with several menus:

a. Ngaji Yuk; this menu will connect the student with a teacher to recite the Qur'an.
b. Subject matter; it contains a link to download learning material to recite the Qur'an.

c. Reminder; it serves to regulate learning hours. The study time for each session is 30 minutes with 2 meetings every week.

d. History; it contains student report cards that record the progress of learning.

e. Help; it provides links to WhatsApp numbers to help if students need it

f. Directory; By clicking on this, students will be directed to the youtube channel of One Qur'an which contains tutorials for learning the Qur'an. 


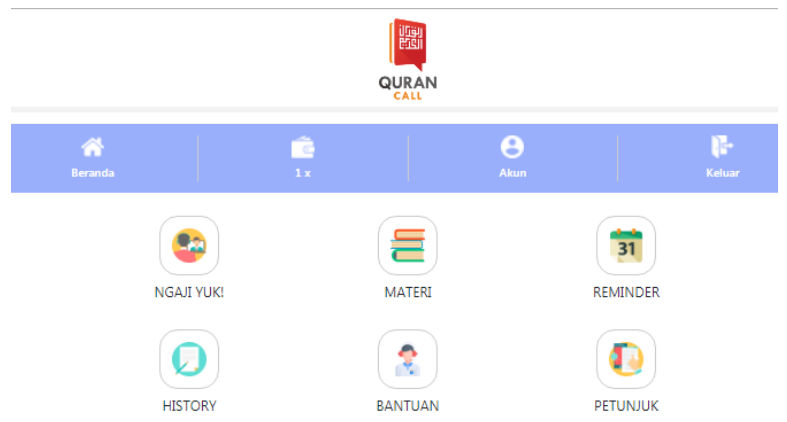

Figure 2. Santri's version of the Qur'anCall Dashboard

The core of a learning program is learning the material. In its history, learning material to recite the Qur'an is always dynamic. Usually, the compilation of books about the learning material of the Qur'an departs from the weaknesses of the previous material. In addition, it is also related to differentiation. In improving the Qur'anCall, the development team also does an analysis of the materials that have been prepared by various traditional methodologies beforehand. At first, the student will be asked to do a placement test to determine the extent of their ability in reciting the Qur'an and determine what courses should be taken.

Uniquely, in the Qur'anCall, the learning material is provided online and can be downloaded in two volumes of digital books (pdf), each consisting of 40 pages and 56 pages. The details of the material are as follows:

a. Volume 1:

1) Introduction of 8 Hijaiyah Letters and 8 Makhorijul Huruf of 8 Hijaiyah Letters

2) Introduction of 10 Hijaiyah Letters and Makhorijul Huruf of 10 Hijaiyah

3) Introduction of 11 Hijaiyah Letters and Makhorijul Huruf of 11 Hijaiyah Letters

4) Introduction to Vocal Recitations Part 1

5) Introduction to Vocal Recitations Part 2

b. Volume 2:

1) Getting to Know and Practice Letter Connect Section 1

2) Getting to Know and Practice Letter Connect Section 2

3) Getting to Know and Practice Vocal Recitations with Many Recitation Variants (Part 1)

4) Getting to Know and Practice Vocal Recitations with Many Recitation Variants (Part 2)

5) Getting to Know and Practice Vocal Recitations with Many Recitation Variants (Part 3)

There are some notes about the materials:

a. The classification of material is groundless. For example, in the first volume 1 the introduction of Hijaiyyah letters and the practice of makhorijul huruf are divided into three. However, the division still uses the order of Arabic alphabets, so the classification is useless. 
b. Lack of practice. On one page, it consists of only one table with three rows and three columns in the average. This is certainly different from the material compiled by traditional methodologies which are wealthy of examples and practice. Moreover, it only consists of two volumes.

c. The artistic appearance. Each page has an image of mural art as the background, with the logo of the PPPA Daarul Qur'an logo in the upper right corner and the Qur'anCall logo in the upper left corner. It can possibly be an advantage or rather a weakness. For example, if it is applied for children, it certainly makes their focus on the core of the fragmented material.

d. The core of the learning material is printed in red to make student more focus. It seems that this style is adopted from the Tajweed colored-mushaf. In the study of the methodology in reciting the Qur'an, such innovation is the first.

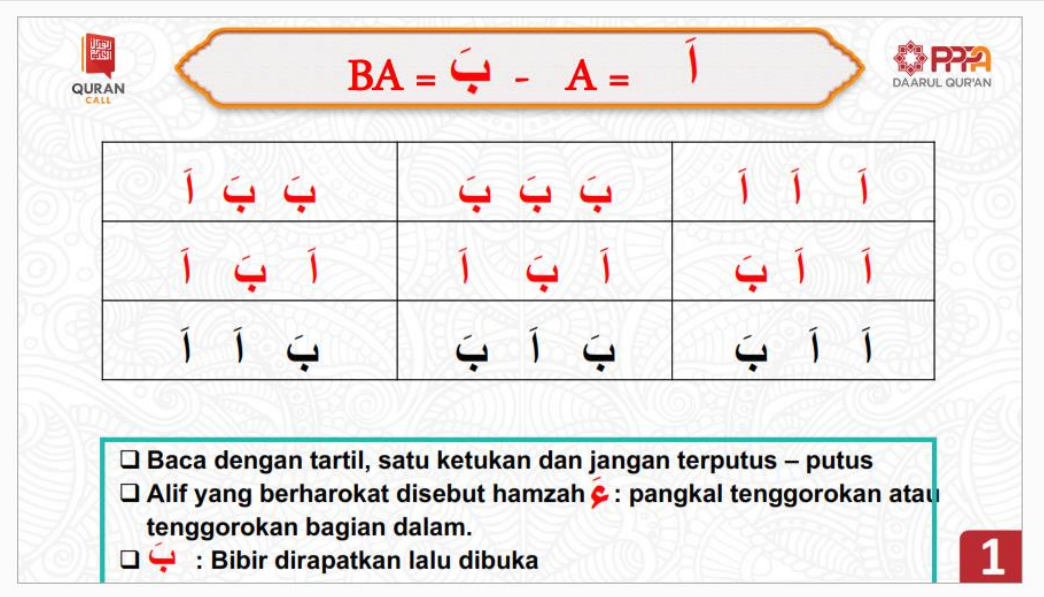

Figure 3. Qur'anCall Learning Material

Another unique one is about financing. To join this program, a student must register first through his website. After that, he will get a free trial of 1-time learning. If he has used this trial opportunity, then he is required to become a premium student by choosing one of several learning packages, as follows:

a. Package 1: A student must pay Rp. 200,000, then he will get 8 meetings.

b. Package 2: A student must pay Rp. 540,000, then he will be able to enjoy recitation of 24 meetings. This includes a 10\% discount because the normal price is Rp. 600,000.

c. Package 3. A student must pay Rp. 1,020,000, then he will get 48 meetings. This also includes a 15\% discount, while the normal price is Rp. 1,200,000.

\section{Teacher: Specifications and Salary}

To be a teacher at the Qur'anCall, a person must register and complete personal data online, then he will get an account to log in. After that, he is required to do an interview via a video call so his ability to recite the Qur'an would be tested. However, as far as I tried, this interview could not be carried out because the 
examiner was always absent. Then prospective teachers are sufficiently directed to send voice recordings of reciting al-Fatihah through WhatsApp to the examiner.

Regarding the payment, the wage of the teacher will be counted by what is called Qur'anCall Point (OQP). The amount to be paid is 16 Qur'anCall Point (OQP) worth Rp. 20,000 / session. The instructor will get 16 OQP if they have taught around 30 minutes.

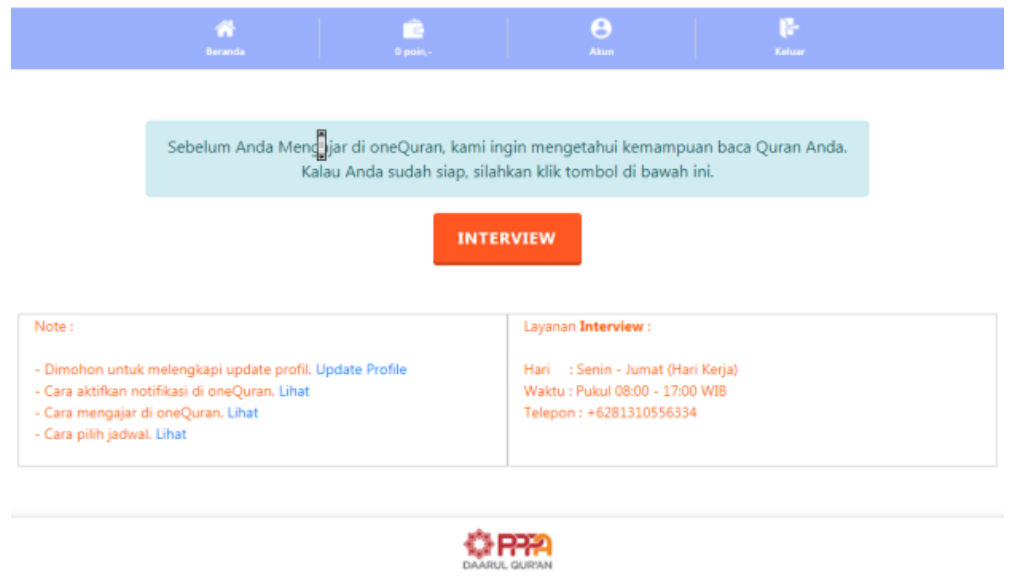

Figure 4. Teacher Qualification Process

\section{The Impact of the Shift from Traditional to Modern Methods \\ Debate on the Sacred}

The most obvious impact of the internet in the Islamic world is the breakup of a liberal and traditional understanding of Islam. ${ }^{23}$ Furthermore, internalization in the interaction of the people with the Holy Book invites a debate on several themes including sacred. As in the early days, when Muslims first adopted printed-media to print the Qur'an, the problem of the sacred become controversial because it was feared to disappear in the media. It is why Muslims always become reluctant in accepting religious printed-books including the Qur'an. However, when the phenomenon of the printed Qur'an was issued by non-Muslims with poor quality and many mistakes, Muslims finally accepted the print media to counter this. Debate with the same pattern (de-sacrality) also took place once new media was encountered by Muslims, such as the voiced-recording of the Qur'an and video learning, as brought up by the Qur'anCall.

In my opinion, this confirms Emily Stewart's argument that the practice of reciting the scriptures, not just the biblical case, will always adapt to new media. Although it is indeed reciting a digitized scripture will reduce the sacredness and the various performative rituals that accompany it. However, both will not be able to get

\footnotetext{
${ }^{23} \mathrm{~V}$. Sisler, "The Internet and the Conrtuction of Islamic Knowledge in Europe," Masaryke. University Journal of Law and Technology 2, no. 2 (2007): 214. 
rid of each other, but rather complement each other. ${ }^{24}$ So, print and face-to-face traditional Qur'an-based media tend to be preferred because they are safe from counterfeiting the Qur'an, typo, medical considerations related to health, etc. ${ }^{25}$ Meanwhile, new digital-based media offer conveniences such as accessibility to learn the Qur'an anywhere and anytime.

Besides, with the presence of the Qur'anCall, learning the Qur'an which previously only took place in Islamic places such as mosques, prayer rooms, TPQ or boarding schools, moved to previously unimaginable places. It certainly challenges the sacredness of the Holy Book which is always upheld, especially in the learning process. In the tradition of the Pesantren Qur'an, the process of learning to read it will be even more sacred. For example, it is well-known among Islamic boarding schools that when a student is learning the Qur'an (talaqqi) directly to his teacher or kyai, it is not only a process of transferring knowledge, but also proving the student's devotion to Allah. If students who are doing talaqqi in a state of immoral conduct, there is a belief that he will not be fluent in reciting the Qur'an, so they must take care of that. Besides, ethics between the student and teacher is so highly respected in the traditional learning method of talaqqi. The beliefs and practices that were born in the dialectics of society with the Holy Books are slowly disappearing with the advent of online learning models of the Qur'an such as the Qur'anCall.

\section{Shifting the Authority of the Qur'anic Teacher}

For modern Muslims, the Internet has now become part of the religious framework. With the internet, people scramble for influence both in one's religious practice and invite them to be affiliated with international religious movements. ${ }^{26}$ One of those affiliated religious practices which affected Muslims is the methodology of learning the Qur'an. The character of new media that is user-friendly has an impact on giving freedom for all people to think and promote their identity. It causes a shift of the authority that previously only revolved among experts. Likewise, in the case of the Qur'anCall, this platform makes it easy to qualify someone who wants to be a teacher of the Qur'an.

Indeed the Qur'anCall has a procedure for selecting prospective teachers, namely administrative selection (filling out biodata forms) and interviews. However, this procedure as far as I tested degrades the qualifications of a Qur'an teacher. Completing the administration form is very easy to falsify, while the interview via a video call cannot be done because the examiner is absent. Instead, prospective teachers are only asked to send their recorded recitations of al-Fatihah to the examiner's number via WhatsApp. This kind of procedure is very different from the standard qualification of the traditional method of reciting the Qur'an which requires

\footnotetext{
${ }^{24}$ Emily R. Stewart, E-Scripture: The Impact of Technology in the Reading of Sacred Texts (Pittsburgh: University of Pittsburgh, 2013), 46.

${ }^{25}$ Muhammad Khuram Kham and Yassir M. Alginahi, "The Holy Quran Digitiation: Chalenge and Concerns," Life Science Journal 20, no. 2 (2012): 164.

${ }^{26}$ Gary R. Bunt, Islam in the Digital Age: E-Jihad, Online Fatwas, and Cyber Islamic Environments (London: Pluto Press, 2012), 211.

Khazanah, Vol. 17 (2), 2019 
the prospective instructor to take an educational program first until he is declared as a graduate and has a diploma as proof that he is eligible to become a teacher of the Qur'an.

In the realm of Islamic science, apart from the adherents of tarekat, the memorizers of the Qur'an are among those who preserve traditions to maintain the chain of transmission of knowledge (sanad) reaching the Prophet Muhammad. ${ }^{27}$ This tradition of sanad is an inheritance that transmitted through face to face learning (talaqqi). The presence of the Qur'anCall certainly challenges the authority of the Qur'an teacher which was previously only in the hands of people who have sanad.

\section{Student Social Cohesion}

Apart from carrying out its primary role in teaching and learning, educational institutions also take part in building social structures in society. It starts with building a social network among graduates. In the traditional learning process that demands face to face learning, inner bonds between students will be formed over time. This bond will carry over until later when students have graduated from their educational institutions. These graduates will work together to help each other so that social cohesion will be formed.

This phenomenon cannot be found in virtual-based education like the Qur'anCall. Inner bonds between fellow students are difficult to form because interactions only occur between a student and a teacher. Fellow students cannot communicate with each other or meet. So, when they finish the program, social networks that function as a forum to integrate the role of graduates in the community are not embroidered strongly. Hence, the benefits of alumni in the community become less.

\section{Learning the Qur'an for all}

In the digital era today, the elaboration of technology in the world of education is important. The existence of E-learning indirectly makes the distribution of education clear. Besides, improvements in the quality, relevance, and efficiency of the learning process can also be resolved. Likewise, with the presence of onlinebased Qur'an learning platforms such as the Qur'anCall, learning the Qur'an which previously could only be done face-to-face, now can be accessed through cyberspace. Certainly, it broadens the range of students who can learn the Qur'an. The flexibility of time can also attract public interest in learning to recite the Qur'an between busy times. Negative feelings such as embarrassment that sometimes afflict elderly people who want to learn the Qur'an can also be overcome with the Qur'anCall. With the help of a laptop and an internet connection, someone can enjoy learning the Qur'an individually without being noticed by anyone. Besides, this platform also plays a role in the dissemination of the Qur'an teacher who is usually only centralized in religious areas.

${ }^{27}$ Zainul Milal Bizawie, "Sanad and Ulama Network of the Quranic Studies in Nusantara," Heritage of Nusantara 4, no. 1 (2015): 28., 28 


\section{The Negative Impact of Technology}

In addition to the positive impacts as described previously, learning the Qur'an based on E-learning also possibly contains negative effects. In the traditional model of learning the Qur'an, an educational organization does not only provide learning material, but also shapes characters, forms personalities, and teaches the ethics and morals of its students. It is very possible because, in traditional learning, students and teachers are in one place at the same time. From there, the behaviour of students can be controlled.

Meanwhile, in the latest learning of the Qur'an such as the Qur'anCall, control cannot be done directly. It is more dangerous because every student learns in the wilderness of cyberspace. If his mentality and personality are not solid, it will be easy for him to fall into negative things that are also carried by the Internet such as online games, pornography, cybercrime, and others.

\section{Conclusion}

Media in the contemporary era has the potential to integrate scriptures in the form of communication with believers. From the analysis above, it appears that the media as intermediaries always come and go. Print media-dominated this process. But, in the middle, there is also contestation between methodologies. Indeed, there is no truly perfect methodology because each has advantages and disadvantages. Baghdadi, Qiroati, Yanbu'a and various methodologies have competed to offer their effectiveness which actually also contained various mixed interests and commodification, from the most subtle to the real.

The presence of online Qur'anic learning such as the Qur'anCall certainly makes it easier for modern people who want to recite the Qur'an fluently but are shy, do not have time, or have difficulty finding teachers. Technical problems which become obstacles in the traditional Qur'anic learning methodology were overcome. On the other hand, this facility also challenges the sacred of the learning of the Qur'an which was only done in Islamic places such as houses of worship or boarding schools. Now, learning the Qur'an can be done almost anywhere and anytime.

One other thing that also shifts is its relation to the authority of the teacher of the Qur'an which in traditional times was in the hands of experts. Among people who hold that authority are the buffaz, with their mandates and the teacher of a certified methodology (Qiroati or Yanbu'a) who has undertaken a series of mentoring programs. With the presence of the Qur'anCall, the qualifications of a Qur'an teacher were reduced. Besides, learning the Qur'an via online is also thick with the motives of commodification. Furthermore, the effectiveness and results of learning still need to be evaluated through further research.

\section{References}

Albab, Ulil. Bimbingan Cara Mengajar Yanbu'a. Kudus: Pondok Tahfidz Yanbu'ul Qur'an, 2004. 
Ally, Mohamed. "Foundation of Educational Theory for Online Learning." In The Theory and Practice of Online Learning. Edmonton: AU Press, 2008.

Atabik, Ahmad. "The Living Qur'an: Potret Budaya Tahfiz Al-Qur'an Di Nusantara." Jurnal Penelitian 8, no. 1 (2014).

Bizawie, Zainul Milal. "Sanad and Ulama Network of the Quranic Studies in Nusantara." Heritage of Nusantara 4, no. 1 (2015).

Bunt, Gary R. Islam in the Digital Age: E-Jihad, Online Fatwas, and Cyber Islamic Environments. London: Pluto Press, 2012.

Gade, Anna M. Perfection Makes Practice: Learning, Emotion, and The Recited Qur'an in Indonesia. USA: University of Hawai'i Press, 2004.

Hanum, Siti Farida. Efektivitas Penerapan Metode Qiraati Terbadap Keterampilan Membaca Huruf Al-Qur'an Di Play Group Plus Al-Afkar Waru Sidoarjo. Surabaya: UIN Sunan Ampel, 2019.

Hidayat, Mansur. "Sedekah Online Yusuf Mansur: Otoritas Dan Bahasa Agama Di Media Sosial." Fikrah 6, no. 1 (2018).

Humam, As'ad. Cara Cepat Membaca Al-Qur'an. Yogyakarta: Team Tadarus AMM, 2000.

Kham, Muhammad Khuram, and Yassir M. Alginahi. "The Holy Quran Digitiation: Chalenge and Concerns.” Life Science Journal 20, no. 2 (2012).

Kinberg, Leah. "Contemporary Ethical Issues." In The Blackwell Companion to the Qur'an. Victoria: Blackwell Publishing, 2006.

Maskhuri, M. Sedekah Dan Gerakan Dakwah Islam: Studi Pemikiran Yusuf Mansur. Semarang: IAIN Walisongo, 2011.

Mujab, Saiful, and Ida Vera Sophya. "Metode Baca Al-Qur'an." Elementary 2, no. 2 (2014).

Nusantara, Yayasan Daarul Qur'an. Profil Lembaga PPP A Daarul Qur'an. Tangerang: Daarul Qur'an, tt.

Rahmayani, Tati. "Pergeseran Otoritas Agama Dalam Pembelajaran Al-Qur'an." Maghza 2, no. 2 (2018).

Sisler, V. "The Internet and the Conrtuction of Islamic Knowledge in Europe." Masaryk University Journal of Law and Technology 2, no. 2 (2007).

Stewart, Emily R. E-Scripture: The Impact of Technology in the Reading of Sacred Texts. Pittsburgh: University of Pittsburgh, 2013.

Ware III, Rudolf T. The Walking Qur'an: Islamic Education, Embodied Knowlwdge, and History in West Africa. Chapel Hill: The University of North Carolina Press, 2014. 